\title{
The Sensitivity Profile of Santri Towards Energy Saving Behavior (Case Study at the Pondok Pesantren Putri Jagad 'Alimussirry)
}

\author{
A A Rofi'ah ${ }^{1}$, A Handrian $^{2}$ \\ ${ }^{1}$ Pondok Pesantren Putri Jagad 'Alimussirry Surabaya, Indonesia \\ ${ }^{2}$ Science Department, Universitas Negeri Surabaya \\ Email: alfired23@gmail.com
}

\begin{abstract}
Pondok Pesantren Putri Jagad 'Alimussirry is one of the Islamic boarding schools in the city of Surabaya. The majority of those living in this pesantren are students and students who are actively studying. Santri (السنتري) based on the review of their actions are "People who adhere to the Qur'an and follow the Sunnah of the Prophet SAW and are firm in their stance." This is the meaning by relying on history and reality that cannot be replaced and changed forever. Santri in general is a term for someone who has attended Islamic religious studies in a place called a pesantren, usually stays in that place until his education is completed. Electricity is a habit carried out by individuals (individuals) or community groups in utilizing sources of electrical energy according to their needs and using them wisely. Pondok Pesantren Putri Jagad 'Alimussirry on the behavior of saving electrical energy and knowing the important role of energy saving behavior for students of the Pondok Pesantren Putri Jagad 'Alimussirry. With this research it is expected that the balance of the santri in the use and utilization of electrical energy
\end{abstract}

Keywords: behavior; santri; save electrical energy.

\section{INTRODUCTION}

One of the energy needs in Indonesia that continues to increase from year to year is the need for electricity. Electrical energy is the main energy needed for electrical equipment stored in electric current in amperes and in electric voltage in volts [7]. Electricity is a form of energy that has an important role in supporting productivity in all fields. Among them are steam power plants (fueled by coal) and gas power plants (fueled by gas). Coal and natural gas are non-renewable sources of energy. Therefore, its utilization must consider the sustainability of energy reserves for the next generation.

The awareness of saving electrical energy is absolutely necessary for all consumers of electrical energy, both household consumers and industrial consumers to maintain the sustainability of energy reserves for the next generation [13]. The forms of saving on electrical energy that can be done include: pulling out unused electrical appliances, turning off and turning on electrical appliances as needed, turning off and turning on lights as needed, adjusting the temperature of air conditioners as needed, and others [2].

To find out the location of the potential savings and efficiency that can be done, a measurement of the level of energy use is previously carried out, known as an energy audit [11]. The form of activity carried out is a measurement of the level of energy consumption known as an energy audit which is carried out to increase awareness to save energy which is carried out to find out how 
much electrical energy is used, calculate the amount of electricity consumption, and identify forms of waste or inefficient use [8].

Pondok Pesantren Putri Jagad 'Alimussirry is one of the Islamic boarding schools in the city of Surabaya. The majority of those living in this pesantren are students and students who are actively studying. In this Pondok Pesantren Putri Jagad 'Alimussirry school, not all of them have the same behavior or habits in responding to the use of electrical energy in everyday life. The students also have their own needs depending on the intensity of use or consumption of electrical energy.

Because the santri of the Pondok Pesantren Putri Jagad 'Alimussirry are busy individuals and have many activities, the electricity needs that are used occur continuously, alternately, even simultaneously. For this reason, it requires saving behavior of electrical energy in the cottage environment. And it takes the awareness of each individual in using electrical energy [1]. Electric energy saving behavior is very necessary in everyday life. Because electrical energy is running low, it requires proper and proper use. With this research, it is hoped that the balance of students in the use and utilization of electrical energy.

Electricity is the power generated by friction or through a chemical process, it can be used to produce heat or light, or to run machines [7]. Electricity is one of the most important elements needed by society for survival. The effect of electricity on life is very large, in the coming period the need for electricity will increase along with the increase and development of the population, the increasing amount of investment will give rise to various kinds of new industries [3]. Electrical energy is a basic need for people both in the industrial and household fields. the use of electrical energy in households, especially for the use of lighting, irons, televisions, laptops, fans, and other electronic devices. The use of these tools cannot be separated from electrical energy, currently in Indonesia it is still using fossil energy sources (petroleum, coal, and natural gas) to generate electricity.

\section{METHOD}

This study uses a qualitative approach with descriptive methods [9]. The problem studied by the researcher is a social problem in which to determine the sensitivity profile of students to energy-saving behavior. This research uses qualitative research using interactive analysis both in data collection, data reduction, data presentation, to drawing conclusions [5]. The analysis of this research is based on written words in the form of documents, in oral form in the form of interviews and the observed behavior in the sensitivity profile of students to energy-saving behavior [6].

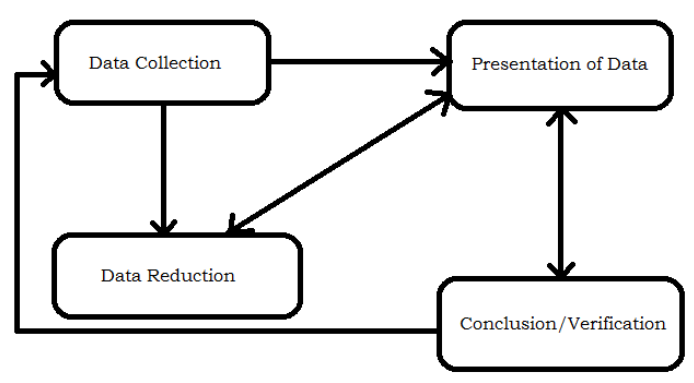

Figure 1. Qualitative Data Analysis according to Miles and Huberman

\section{RESULT AND DISCUSSION}

A. Understanding the Energy Saving Behavior of Santri at the Pondok Pesantren Putri Jagad 'Alimussirry

1. Case finding of santri behavior that does not reflect saving electrical energy

The cottage environment is the residence (house) for the snatri who lives in it. This causes the accumulation (mixing) of various kinds of characteristics, attitudes, personalities, and various habits. In the use of various electrical equipment, there are those who have the habit of charging their cellphones while sleeping, some turn on their laptops until they fall asleep, some turn on the water faucet and forget to turn off, some 
forget to turn off the fan, some don't turn off the lights even though it's daytime, and some forget to unplug the iron after ironing. These things are very often encountered by santri in the 'alimussirry female boarding school environment', 7 out of 7 interviewees said that they had encountered the cases mentioned above.

2. The concern of the santri towards saving electrical energy behavior

According to the Big Indonesian Dictionary (KBBI) an action is an act or something that is done [4]. From the interviews that the researchers have conducted, the results are in the form of actions of the students when they encounter several cases that occur, actions in the form of directly pulling out the cable, cutting off electricity immediately is a form of concern for the santri towards saving electrical energy behavior.

\section{B. Electric Energy Saving Application at}

the Pondok Pesantren Putri Jagad

'Alimussirry

The behavior of saving electrical energy is a pattern or habit that is carried out in using electricity according to the needs with the aim of reducing the amount of excessive electricity consumption [3]. The main reason for saving electric energy is to keep the cost of electricity consumption to a minimum, reduce pollution caused by burning the main fuel electricity, conserve natural resources, and reduce global warming. Saving electrical energy is intended so that future generations can enjoy and use electrical energy, reducing the impact caused by global warming. Here are some ways to save electricity needs.

1. Disconnect cables that are finished or not in use

2. Turn off the light while sleeping
3. Do not turn on the lights during the day

4. Be wise in using electronic items such as irons, fans, laptops, hook machines, and others

5. Do not leave electronic devices on while sleeping..

C. Opinion of students on the

implementation of Energy Saving

Electricity at the Pondok Pesantren

Putri Jagad 'Alimussirry

1. The percentage of students' sensitivity to energy saving behavior

Almost all of the interviewees stated that the behavior of saving electrical energy in the Alimussirry Putri Jagad Islamic Boarding School has implemented it, but it does not rule out that there are still those who are indifferent to the energy-saving behavior of electricity caused by forgetting or other things. Based on the average percentage of energy-saving behavior in the Pondok Pesantren Putri Jagad 'Alimussirry, the result is $59.3 \%$.

2. Suggestions that all students can apply my behavior to save electrical energy

According to the Big Indonesian Dictionary (KBBI) the meaning of suggestions is an opinion (suggestion, suggestion, aspiration) put forward for consideration [4]. Based on the results of the interviews the researchers obtained, some suggestions can be drawn from the students so that all santri at the Pondok Pesantren Putri Jagad 'Alimussirry can apply the following electrical energy saving behavior.

a. Self-awareness is the main key to applying energy-saving electricity. 
b. Remind each other of the importance of saving electrical energy.

c. Socialization of the importance of conserving electrical energy, the impact of wasteful use of electrical energy and the dangers of leaving the room with electronic equipment on or plugged into the socket.

d. Train yourself to save from everything, including the consumption of electrical energy.

\section{CONCLUSION}

The behavior of saving electrical energy is a habit carried out by individuals in reducing the amount of electrical energy use and using electrical energy as needed. Here's an effective way to save electricity use.

1. Turn off the lights when leaving the room or after using the bathroom.

2. Unplug the cable / charger after charging or that are not in use

3. Turn off electronic equipment such as fans and irons, when not in use or after use

4. Turn off the faucet when the bath is full

5. Does not charge laptops or cellphones while sleeping

The purpose of saving electrical energy is so that it can be used in the future and reduce electricity bills. The energy-saving behavior of the students has the following benefits: 1) saving money and reducing monthly expenses incurred by the boarding school; 2) reduce pollution in the form of heat and noise; 3) maintaining the balance of natural resources; 4) take care of the students' electronic devices: 5) avoid the risk of short circuits (short circuit). In addition, the behavior of saving electrical energy that is applied by students reflects the praiseworthy nature of the hadith from Ibn 'Umar ra Rasulullah SAW said "being economical is half of life (HR. AlSyihab) [10].

\section{REFERENCES}

[1] S. Ali, 2013, Paradigm pesantren: memperluas horizon kajian dan aksi, Malang: UIN Maliki Press.

[2] H. Assael, 2000, Perilaku Konsumen dan Pemasaran, Edisi keenam, Jakarta: Salemba Empat.

[3] I. S. Chahaya, 2005, Pengetahuan, Sikap Dan Tindakan Masyarakat Dalam Upaya Menghemat Pemakaian Energi Listrik di Perumahan Nasional (PERUMNAS) Kota Medan, Jurnal Komunikasi Penelitian, Vol 17 (4).

[4] KBBI, 2016, Kamus Besar Bahasa Indonesia (KBBI), Availableat:http://kbbi.web, id diakses 4 Januari 2020.

[5] M. B. Miles dan A. M. Huberman, 2007, Analisis Data Kualitatif, Buku Sumber Tentang Metode-metode Baru, Jakarta: Universitas Indonesia Press.

[6] Moeleong, 2011, Metodologi Penelitian Kualitatif, Bandung: PT Remaja Rosdakarya.

[7] Pujiono. 2013. Rangkaian Listrik. Graha Ilmu: Yogyakarta.

[8] Siswanto, 2010, Manajemen Personalia Manajemen Sumber Daya Manusia. Jakarta: Ghalia Indonesia.

[9] Sugiyono, 2013, Memahami Penelitian Kualitatif, Bandung: CV. Alfabeta.

[10] Najirah, 2014, Pemahaman Hadits tentang Pola Hidup Sederhana (Kajian Fiqh alHadits), Skripsi, Ushuluddin dan Humaniora, UIN Antasari. 